Annals of Warsaw University of Life Sciences - SGGW

Land Reclamation No 50 (3), 2018: 215-227

(Ann. Warsaw Univ. of Life Sci. - SGGW, Land Reclam. 50 (3), 2018)

\title{
Flow characteristics of intermittent rivers in Slovakia
}

\author{
AGNIESZKA RUTKOWSKA ${ }^{1}$, SILVIA KOHNOVÁ ${ }^{2}$, KAZIMIERZ BANASIK $^{3}$, \\ JAN SZOLGAY ${ }^{2}$ \\ ${ }^{1}$ Faculty of Environmental Engineering and Land Surveying, University of Agriculture in Krakow, \\ Poland \\ ${ }^{2}$ Faculty of Civil Engineering, Slovak University of Technology in Bratislava, Slovakia \\ ${ }^{3}$ Faculty of Civil and Environmental Engineering, Warsaw University of Life Sciences - SGGW, \\ Poland
}

\begin{abstract}
Flow characteristics of intermittent rivers in Slovakia. Intermittent rivers are rivers that cease to flow, i.e. temporary, ephemeral, seasonal, and episodic rivers. Analysis of hydrological regime of such rivers is pivotal in assessment of water resources because changes in flow characteristics of such rivers may affect neighboring catchments or the entire region through changes in water supply reservoirs such as lakes, wetlands and mosses. Recently, an increasing number of intermittent rivers and ephemeral streams (IRES) and an elongation of the zero-flow events has been observed in Europe due to climatic changes and anthropogenic influence. Intermittent rives in Slovakia were studied in the paper using statistical methods. The characteristics of the zero-flow period, of duration of the longest annual zero-flow event and of timing of such events were derived. The circular statistics were helpful in recognition of the dates of occurrence of such events. The comparative analysis between catchments was performed. The variability in precipitation and evapotranspiration and the increasing temperature were identified as the possible drivers of the flow intermittence in these catchments. The research was performed within the COST Action SMIRES (Science and Management of Intermittent Rivers \& Ephemeral Streams).
\end{abstract}

Key words: periodic river, IRES, zero-flow event, characteristics of intermittence, angular dates

\section{INTRODUCTION}

Intermittent rivers are all rivers that that periodically cease to flow. The term is used for all temporary, ephemeral, seasonal, and episodic streams and rivers in defined channels. It is estimated that these types of rivers make up over 30\% of the total length and discharge of the global river network (Datry et al. 2014). These estimates do not include low-order streams as such streams usually do not have monitoring gauging stations and little data is available for them. As such, the proportion of intermittent rivers in the global river network is likely to be greater than $50 \%$. More and more rivers and streams around the world, including some of the world's largest rivers, are becoming intermittent rivers as humans extract their water for drinking and irrigation and as a result of land-use alterations and climate change (Datry et al. 2016).

Intermittent streams, particularly the first and second order channels, make up most of the channel network at the catchment scale, however, their preva- 
lence depends on climatic zones. As tributaries to larger rivers, intermittent rivers play a significant role in the dynamics of materials. The interrelationships between rainfall, catchment topography, human activity and climate change also mean that intermittent streams occur in a variety of landscape (Bond and Cottingham 2008). Some recent research demonstrates the decreasing trends in mean annual flow are prevailing in observation records in Poland (Piniewski et al. 2018). This has also been indicated in a long term study of a small lowland catchment area in the center of Poland (Banasik and Hejduk 2012, Banasik at al. 2013). No flow in Carpathian creeks is also occasionally documented (Więzik 2015). The importance of this type of river has also been extensively researched by the U.S. Environmental Protection Agency which has sought to protect the bodies of water that flow intermittently (Acuna 2014). Intermittent rivers dry up during the dry season, particularly in semi-arid regions. However, zero flow may also occur during drought in temperate regions, especially in quickly responding catchments (Gustard and Demuth 2008). Climate change and various anthropogenic activities such as land-use alterations and water abstractions increase the occurrence, duration, and frequency of river drying (Larned et al. 2010, Döll and Schmied 2012). Intermittent rivers and ephemeral streams (IRES) have a highly variable flow regime implications of which can be negative for ecological processes in their catchments (Leigh et al. 2016, Stubbington et al. 2017). This is because the equilibrium of the catchment ecosystem can be perturbed dur- ing the zero-flow event due to sediment and microorganisms transport issues.

The methods for describing or characterizing low flow hydrology are well developed for perennial streams as they usually have adequate gauging data. The purpose of this investigation has been to analyze the timing and frequency of dry periods of seven Slovakian intermittent rivers.

\section{MATERIAL AND METHODS}

Slovakia is characterized by large climate and topographical variability between the lowland areas of the Pannonia Plain and the highest elevations in the Carpathian Mountains. The selected study area is situated in a temperate climate zone at the border of the Atlantic and the continental part of Europe. The mean annual temperature varies from about $10^{\circ} \mathrm{C}$ in the lowlands to less than $-3^{\circ} \mathrm{C}$ in the Tatra Mountains. The mean annual precipitation also exhibits strong spatial variability. A general decrease of precipitation along the West to the East gradient is imposed by orographic enhancement. The lowest precipitation occurs in the lowlands (less than $400 \mathrm{~mm} /$ year), while the highest precipitation totals occur on the windward slopes of the Tatra Mountains (more than $1,500 \mathrm{~mm} / \mathrm{year}$ ).

In the territory of Slovakia, together seven basins with intermittent rivers (IRES) were selected. The criterion for selection of IRES was set by the COST SMIRES Working Group 1 in 2017. The intermittent rivers and ephemeral streams must fulfill following criteria: at least one event with discharge lower or equal to one liter per second for daily 
data; for weekly data seven consecutive days (i.e. one record) with this discharge value; for monthly - one month. Additionally, the minimum time series length is 10 years, with less than $5 \%$ of missing days. The rivers must be natural without anthropogenic influence. It was not easy to find rivers fulfilling these criteria in Slovakia. Finally the dataset consist of seven catchments with IRES and their location is presented in Figure 1. The rivers are located in various parts of Slovakia, representing lowlands, namely the East Slovakian Lowland (Chlmec) and the Danubian Lowland (Čierna Voda), karstic area (Bodva, Turiec) as also hilly regions (Myjava, Slavkovský potok, Budinský potok).

The dataset for Slovakia was complemented with discharge data from the Slovak Hydrometeorological Institute in Bratislava (Table 1). For the statistical analysis we have collected the mean daily discharge from the whole observation period, which varied between years 1960-2016. The drainage area varies from $19.04 \mathrm{~km}^{2}$ for the smallest catch- ment Budinský potok to $193.6 \mathrm{~km}^{2}$ for the larges Bodva river basin. The latitude of the river outlets is between 100-450 m a.s.l. The proportion of zero-flow in a year which is the number of all records with flow lower or equal to $1 \mathrm{l} / \mathrm{s}$ divided by record length, was very low which shows that intermittence events are rare. The lowest value of this proportion was in the Myjava and the highest was in the Čierna Voda. Catchment characteristics are presented in Table 1. The table contains abbreviations of the rivers' names used in the paper.

For every river, the characteristics of intermittence were derived, namely characteristics (i) of the zero-flow periods, (ii) of duration of the longest annual zero-flow event, and (iii) of timing. The empirical distribution functions of zero-flow periods and of duration were also found.

Among the characteristics of zero-flow periods, $n_{0}$ is the total number of days with zero-flow, $f$ is the fraction of zero-flow years which is the number of years with zero-flow divided by the total number of years, $m_{a}$ is the mean annual

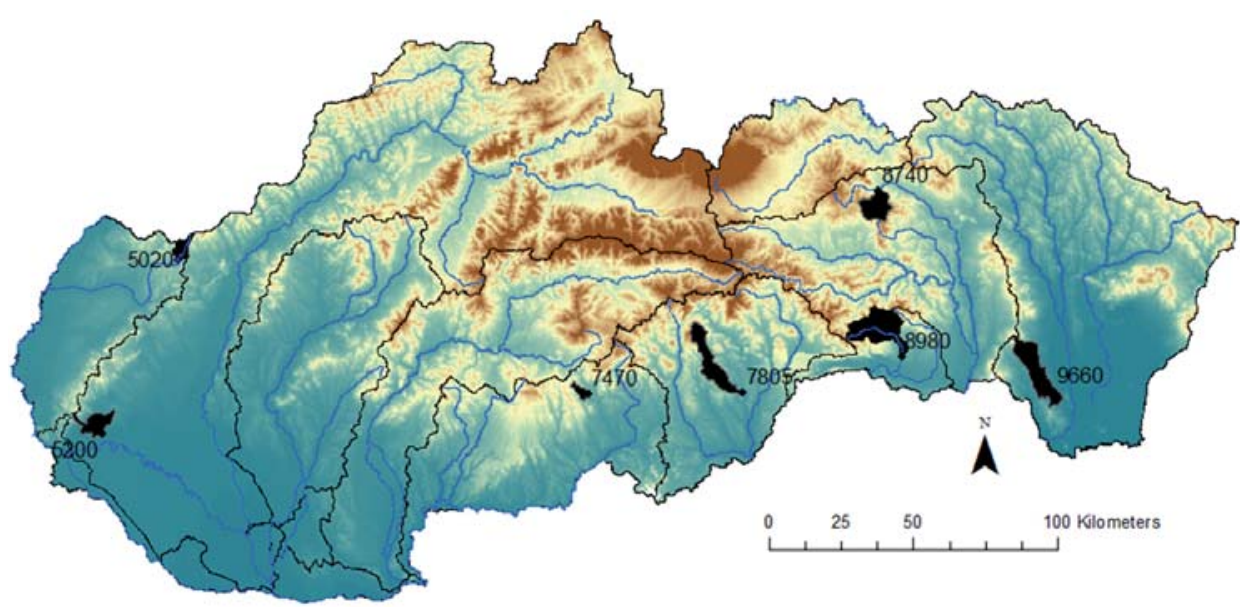

FIGURE 1. Location map of selected IRES catchments in Slovakia 
TABLE 1. List of selected IRES catchments with their basic catchment characteristics

\begin{tabular}{|l|c|c|c|c|c|c|}
\hline $\begin{array}{l}\text { River / Gauging } \\
\text { station }\end{array}$ & Abbrev. & $\begin{array}{c}\text { Area } \\
\left(\mathrm{km}^{2}\right)\end{array}$ & $\begin{array}{c}\text { Period } \\
\text { of } \\
\text { observation }\end{array}$ & $\begin{array}{c}\text { Altitude } \\
\text { of the outlet } \\
(\mathrm{m} \text { a.s.1. })\end{array}$ & $\begin{array}{c}\text { Daily mean } \\
\text { discharge } \\
\left(\mathrm{m}^{3} / \mathrm{s}\right)\end{array}$ & $\begin{array}{c}\text { Proportion } \\
\text { of zero-flow }\end{array}$ \\
\hline $\begin{array}{l}\text { Čierna Voda / } \\
\text { Bernolákovo }\end{array}$ & CIE & 72.18 & $1960-2015$ & 125.27 & 0.33 & 0.0199 \\
\hline Myjava / Myjava & MYJ & 33.09 & $1973-2012$ & 324.34 & 0.28 & 0.0027 \\
\hline $\begin{array}{l}\text { Budinský potok / } \\
\text { Divín }\end{array}$ & BUD & 19.04 & $1968-2016$ & 261.41 & 0.11 & 0.0076 \\
\hline $\begin{array}{l}\text { Turiec / } \\
\text { Gemerská Ves }\end{array}$ & TUR & 131.61 & $1992-2016$ & 191.02 & 0.66 & 0.0125 \\
\hline $\begin{array}{l}\text { Bodva / } \\
\text { Moldava nad } \\
\text { Bodvou }\end{array}$ & BOD & 193.6 & $1964-2015$ & 203.54 & 1.22 & 0.0067 \\
\hline $\begin{array}{l}\text { Slavkovský potok / } \\
\text { Brezovica }\end{array}$ & SLA & 83.5 & $1972-2016$ & 452.18 & 0.45 & 0.0034 \\
\hline $\begin{array}{l}\text { Chlmec / } \\
\text { Zemplínsky Branč }\end{array}$ & CHL & 145.24 & $1973-2015$ & 102.36 & 0.33 & 0.0178 \\
\hline
\end{tabular}

* In the period of observation.

number of zero-flow days which is the total number of zero-flow days divided by the number of years, and $\sigma_{a}$ is the standard deviation of the annual number of zero-flow days. These characteristics reflect the frequency of zero-flows in the study period.

Among the characteristics of duration, $m_{d}$ is the mean duration of the longest annual zero-flow event, and $\sigma_{d}$ is the standard deviation of the longest annual zero-flow event.

To derive the characteristics of timing, the dates of the zero-flows days were selected to the samples in every catchment. The angular characteristics were derived according to Mardia and Jupp (2000) as follows. Every date was converted to Julian date $D_{i}, i=1, \ldots, n$, i.e. $D_{i}=1$ for 1 st January and $D_{i}=365$ for 31 st December when it is not a leap year and when $n$ is the sample length. Subsequently, every Julian date $D_{i}$ was converted to angular value using the formula $\Theta_{i}=\left(D_{i} \cdot 2 \pi\right) /$ 1365 (rad). In leap years, the denominator was increased by one. The value $\Theta_{i}$ is a measure of the counterclockwise-directed angle between the vectors $[1,0]$ and $\left[x_{i}, y_{i}\right]$ assigned to a point $(0,0)$ with endpoints on the unit circle where $\left(x_{i}, y_{i}\right)=$ $=\left(\cos \Theta_{i}, \sin \Theta_{i}\right)$. Therefore, the dates $\Theta_{i}$ can be associated with points located on the unit circle. Such a one exemplary date is depicted in Figure 2.

Assuming that $(\bar{x}, \bar{y})=\left(\frac{1}{n} \sum_{i=1}^{n} \cos \Theta_{i}\right.$, $\left.\frac{1}{n} \sum_{i=1}^{n} \sin \Theta_{i}\right)$, the mean angular date is

$$
\bar{\Theta}=\left\{\begin{array}{l}
\operatorname{arctg} \frac{\bar{y}}{\bar{x}} \text { if } \bar{x}>0, \bar{y} \geq 0 \\
2 \pi+\operatorname{arctg} \frac{\bar{y}}{\bar{x}} \text { if } \bar{x}>0, \bar{y}<0 \\
\pi+\operatorname{arctg} \frac{\bar{y}}{\bar{x}} \text { if } \bar{x}<0 \\
\frac{\pi}{2} \text { if } \bar{x}=0, \bar{y}>0 \\
\frac{3 \pi}{2} \text { if } \bar{x}=0, \bar{y}<0
\end{array}\right\}
$$




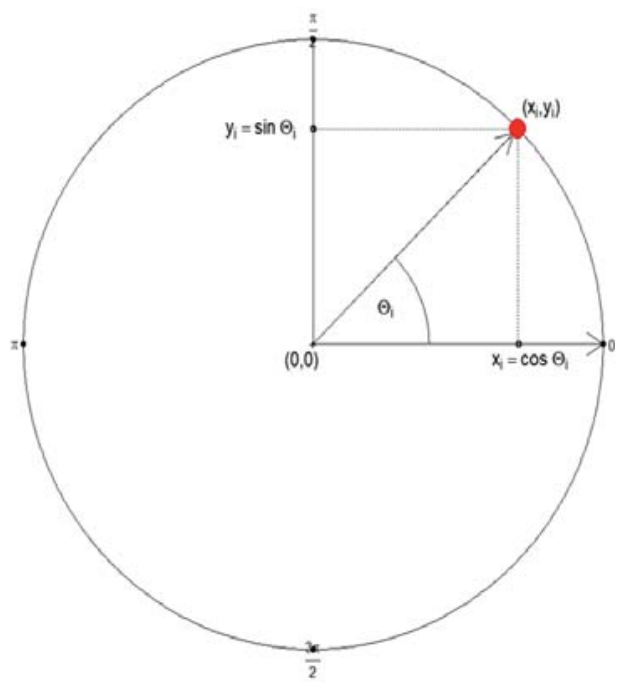

FIGURE 2. The date of occurrence depicted on an explanatory plot. The entire circle is one year, while the 1st January is at the angle 0 , the first quarter of the year is at the angle $\frac{\pi}{2}$ etc. The big, red point illustrates the date under consideration. It is associated with the angle $\Theta_{i}$ which is the angular date of the occurrence. The coordinates of the red point are $\left(x_{i}, y_{i}\right)=\left(\cos \Theta_{i}, \sin \Theta_{i}\right)$

It can be observed that $\bar{\Theta} \in[0,2 \pi)$. Using the formula $\bar{D}=\frac{\bar{\Theta} \cdot 365}{2 \pi}$, the mean angular date can be converted to the mean Julian date. The dispersion of dates can be measured using the mean resultant length $\bar{r}=\sqrt{\bar{x}^{2}+\bar{y}^{2}}$. It is worth noting that $0<\bar{r} \leq 1$ and that $\bar{r}$ near to 1 implies little dispersion and high concentration while $\bar{r}$ near to 0 implies large dispersion and low concentration. The standard deviation equal to $\sigma=\sqrt{-2 \ln \bar{r}}$ is also often used. The following characteristics of timing of intermittence were derived: $\bar{\Theta}_{1 s t}, \bar{r}_{s t}, \sigma_{1 s t}-$ the mean circular date, the mean resultant length and the standard deviation of the first annual zero-flow day, respectively. Similarly, $\bar{\Theta}_{\text {all }}, \bar{r}_{\text {all }}, \sigma_{\text {all }}$ are the mean circular date, the mean resultant length and the standard deviation of all zero-flow days in a year.

All calculations were carried out in R (R CORE TEAM 2017). The package 'smires' was used (Gauster 2017).

In studies on seasonality of various meteorological and hydrological events, the Markham method is often used (Markham 1970, Dingman 2002). This method is becoming increasingly applicable (Livada and Asimakopoulos 2005, Petersen et al. 2012, Baran-Gurgul and Raczyński 2016, Jokiel and Stanisławczyk 2016, Moniewski 2016). To explain the similarity between the circular statistics and the Markham indices, let assume that $360^{\circ}$ of the polar coordinate system are apportioned to twelve angles representing twelve months of the calendar year. Every data from the sample of monthly values (e.g. monthly rainfall totals) is depicted as a vector of direction linked with its month and of magnitude linked with its value. The Markham seasonality index is the length of the resultant vector divided by the sum of the lengths of components. The Markham concentration index is the anticlockwise directed angle between the resultant vector and the $O X$ axis. It represents the peak month of rainfall occurrence. It can be observed that there is a similarity between Markham indices and circular statistics because the date of occurrence is associated with an angle in both methods. However, the dissimilarity is in the magnitude of the vector equal to the data value (monthly rainfall totals) in the Markham method and equal to one in circular statistics because seasonal data (month and magnitude) are depicted 
in the Markham method and the dates of occurrence of random data are depicted in circular statistics. Summarizing, both methods are usually applicable for various data types. If the daily data instead of the monthly ones are used and if only dates instead of dates and magnitudes are studied, then the Markham method is equivalent to the circular statistics-based method. Then, the concentration index equals to the circular mean angular date given by Equation (1). In this study, the mean angular date of the first annual zero-flow day is just the Markham concentration index in the daily-based approach.

\section{RESULTS AND DISCUSSION}

The main characteristics of the intermittence were shown in Table 2. The zero-flow events were rare in the MYJ, BUD and SLA rivers in the study period which is reflected in a very low fraction of zeroflow years in these catchments. This is also visible in the low $m_{a}$ and $m_{d}$ values. The number of annual zero-flow days varies little in the MYJ and SLA catchments because of low $\sigma_{a}$ values. The deviation of the duration of zero-flow events is also low there because of the low $\sigma_{d}$ value, especially in the SLA river. Among all IRES rivers, the CIE river shows the largest mean annual number of zero-flow days and the second longest mean duration of such events. Similarly, the CHL river shows the largest mean duration and the second largest mean annual number of zero-flow event. The variability of these two variables is the highest in these two catchments because of the largest $\sigma_{a}$ and $\sigma_{d}$ values. The con- clusion that can be drawn from the above is that the CIE and the CHL rivers were the most susceptible to intermittence and the most responsive to drought (Fendeková et al. 2017).

The time series plots of the annual total zero-flow days and of the duration of the longest event enabled the long-term pattern of the events to be recognized in Figure 3. It can be concluded from these figures that the catchments differ by the frequency of zero-flow events. In most catchments, apart from the CIE river, the zero-flow events were observed not earlier than in 1980s. It is worth noting that in several years with zero flow, the total annual duration of zero-flow events was nearly equal to the duration of the longest event because the height of the bars is similar in years 1978, 1991 and 1993 in the CIE river, in 1990 in the MYJ river, in 2012 in the TUR river, and in 2015 in the CHL river. Therefore, only one event per year was noticed in these years. In the rest of years with zero-flow, the number of events was also not high. The low frequency of years with zero-flow is apparent in the MYJ, BUD and SLA rivers (Figs. 3b, 3c, 3f), namely between two and four events in the entire period of observation. Another group, with higher frequency, is composed of catchments TUR and BOD (Figs. $3 \mathrm{~d}$ and $3 \mathrm{e})$ where the number of zero-flow years was five. Moreover, these two rivers had similar zero-flow years at the beginning of 1990s and in 2012. The next group consists of the CIE and CHL rivers (Figs. 3a, 3g) with the highest frequency and the largest number of years with zero-flow, exceeding five. A very long, 86-day lasting zero-flow event was recorded in 2015 in the CHL river due to a 
TABLE 2. Characteristics of intermittence

\begin{tabular}{|l|c|c|c|c|c|c|c|c|c|c|c|}
\hline River & $f$ & $\begin{array}{c}m_{a} \\
\text { (day) }\end{array}$ & $\begin{array}{c}\sigma_{a} \\
(\text { day) }\end{array}$ & $\begin{array}{c}m_{d} \\
(\text { day })\end{array}$ & $\begin{array}{c}\sigma_{d} \\
(\text { day })\end{array}$ & $\begin{array}{c}\bar{\Theta}_{1 s t}(\mathrm{rad}) / \\
/ \bar{D}_{1 s t}(\text { day })\end{array}$ & $\begin{array}{c}\bar{r}_{1 s t} \\
(-)\end{array}$ & $\begin{array}{c}\sigma_{1 s t} \\
(\mathrm{rad})\end{array}$ & $\begin{array}{c}\bar{\Theta}_{\text {all }}(\mathrm{rad}) / \\
/ \bar{D}_{\text {all }}(\text { day })\end{array}$ & $\begin{array}{c}\bar{r}_{\text {all }} \\
(-)\end{array}$ & $\begin{array}{c}\sigma_{\text {all }} \\
(\mathrm{rad})\end{array}$ \\
\hline CIE & 0.23 & 7.2 & 17.4 & 4.5 & 11.7 & $3.89 / 226.1$ & 0.95 & 0.32 & $4.43 / 257.4$ & 0.89 & 0.49 \\
\hline MYJ & 0.05 & 1.0 & 6.2 & 1.0 & 6.2 & $5.06 / 294.0$ & 0.41 & 1.34 & $4.26 / 247.4$ & 0.95 & 0.33 \\
\hline BUD & 0.08 & 2.7 & 12.8 & 1.3 & 5.5 & $3.27 / 190.2$ & 0.90 & 0.45 & $3.79 / 220.3$ & 0.88 & 0.51 \\
\hline TUR & 0.20 & 4.4 & 14.2 & 3.6 & 11.6 & $3.71 / 215.4$ & 0.92 & 0.40 & $4.02 / 233.5$ & 0.93 & 0.38 \\
\hline BOD & 0.12 & 2.4 & 9.8 & 1.2 & 4.5 & $3.73 / 216.5$ & 0.91 & 0.43 & $4.28 / 248.7$ & 0.94 & 0.36 \\
\hline SLA & 0.04 & 1.2 & 6.0 & 0.8 & 3.7 & $5.64 / 327.5$ & 0.12 & 2.08 & $5.04 / 293.0$ & 0.26 & 1.65 \\
\hline CHL & 0.14 & 5.9 & 19.1 & 4.8 & 16.2 & $3.51 / 203.9$ & 0.95 & 0.33 & $4.04 / 234.9$ & 0.92 & 0.40 \\
\hline
\end{tabular}

Characteristics of the number of zero-flow days: $m_{a}-$ mean annual number of zero-flow days, $\sigma_{a}-$ standard deviation of the number of zero-flow days.

Characteristics of the longest annual zero-flow event: $m_{d}$ - mean duration of the longest annual zero-flow event, $\sigma_{d}$ - coefficient of variation.

Characteristics of timing of the first annual zero-flow day: $\bar{\Theta}_{1 s t}-$ mean circular date, $\bar{D}_{1 s t}-$ mean date, $\bar{r}_{1 s t}$ - mean resultant length, $\sigma_{1 s t}$ - standard deviation of the first annual zero-flow day.

Characteristics of timing of all zero-flow days in a year: $\bar{\Theta}_{\text {all }}$ - mean circular date, $\bar{D}_{\text {all }}$ - mean date, $\bar{r}_{\text {all }}$ - mean resultant length, $\sigma_{a l l}-$ standard deviation.

severe drought (Fendeková et al. 2017). Other rivers did not show intermittence in this year, apart from the MYJ river where the period of observation did not cover the year 2015. The intermittence was also noticed during the drought in 2012 (Fendeková et al. 2017) in rivers BUD, TUR, BOD, SLA with the longest events lasting 35 and 26 days in the BUD and TUR rivers, respectively. The TUR and BOD catchments are placed in the Slovak Karst with a high stream gradient and with numerous rapid cascades and waterfalls. This region is extremely exposed to negative consequences of extreme hydrological events because both floods and droughts may cause ecological injuries (Vološčuk et al. 2016).
The three groups of catchments differ by topographic conditions. The first group (MYJ, BUD, SLA) consists of catchments located on hilly areas with the largest mean elevation (Table 1). The catchments from the second group (TUR, BOD) are moderately elevated. The catchments from the third group (CIE, CHL), in turn, located in lowland areas, have the lowest elevation.

The causes of zero-flow events are complex and can result from various factors as geology, morphology, climate etc. The spatial distribution of annual precipitation in Slovakia shows that the northern part of Slovakia has about $1,000-1,500 \mathrm{~mm}$ of annual precipitation, but in southern parts of the country only 

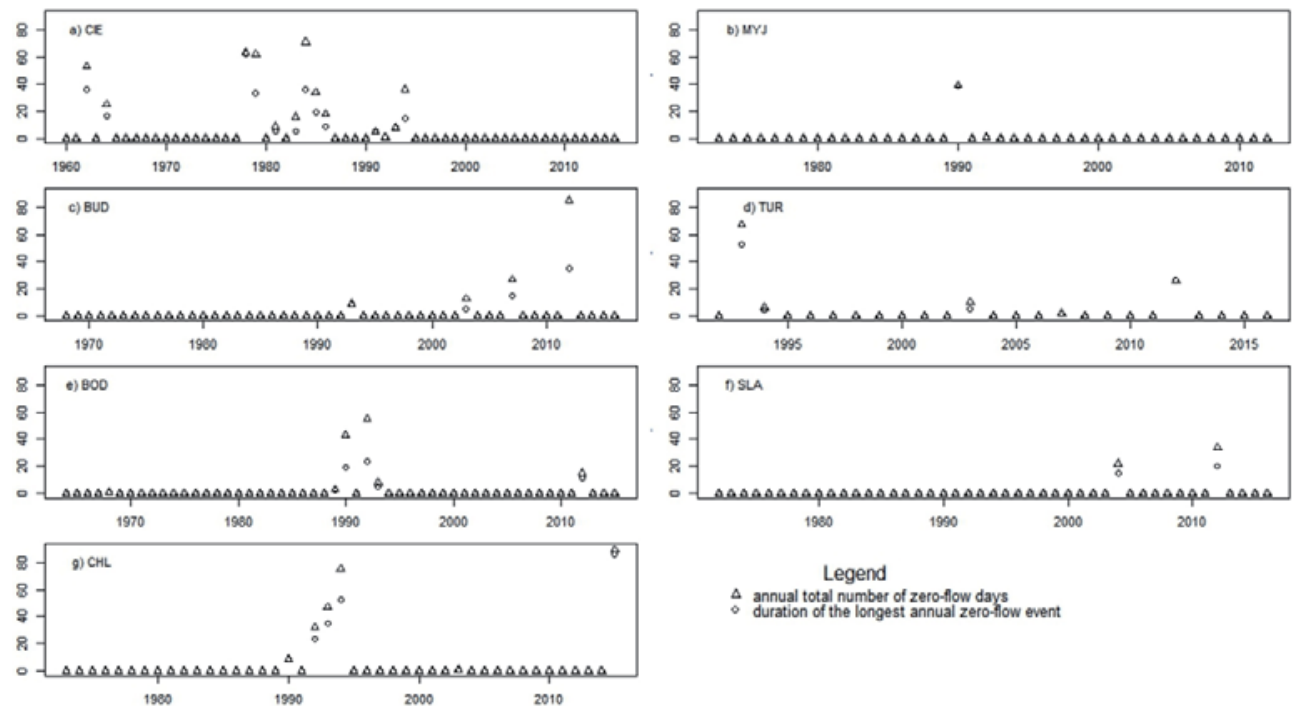

1990

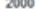

2010

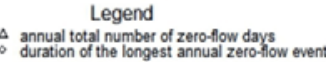

FIGURE 3. The time series plots of the annual total number of zero-flow days and of the duration of the longest annual no-flow event

about $400 \mathrm{~mm}$ in a year (Zeleňáková et al. 2017). This explains the prevailing location of the intermittent rivers in the south of the country. For the analysed catchments the mean annual precipitation is lower than $700 \mathrm{~mm}$ annually.

A slight decrease in precipitation and a significant increase in the mean air temperature are shown by many authors to have an impact in various parts of Slovakia (Melo et al. 2007, Lapin et al. 2009, Pecho et al. 2009). Therefore, decrease in runoff during last decades up to $30 \%$ can possibly be explained by the impact of climate change (Lapin et al. 2009, Labudová et al. 2015).

The MYJ, TUR, SLA rivers belong to the middle warm mountainous climate, while the rest of the analysed rivers belong to the warm lowland climate. The MYJ, TUR, SLA and BOD rivers have rainfall-snowmelt runoff regime, with the highest mean monthly discharges in February and March and the low- est during the autumn months September-October and winter months December-January. The BUD, CIE and CHL rivers show dominant rainfall regimes with highest runoff during May-June and lowest during autumn August-October. The concentration of the zero-flow events mostly after the year 1980 is in agreement with longer droughts in this period due to increasing mean annual air temperature up to $+2^{\circ} \mathrm{C}$ and increasing potential evapotranspiration (Labudová et al. 2015).

Long drought periods in the early 1960 s, early 1970 s, and early and mid-1990 s, as also during the years 2002 -2003 and 2011-2012 were mentioned for the Danubian Lowland by Labudová et al. (2017) who studied the standardized precipitation index (SPI) and the standardized precipitation evapotranspiration index (SPEI) in the period 1961-2013 on a monthly base. This can explain higher frequency of zero-flow events in the CIE 
river, namely in years 1962 and 1964 when the total number of zero-flow days was 53 and 25, and in 1994 (15 days). The longest event of 62 days was noticed in 1978 in the CIE river which coincidences with a low three-monthly SPI in late 1970s in this region (Labudová et al. 2017). Another authors, e.g. Lapin et al. (2009), indicate an increase of temperature, followed by increase of actual evapotranspiration and decrease of air humidity in recent several dozen years in various parts of Slovakia with considerable changes in the southern part of the country. The authors stress a higher percentage of evaporated rainfall and a lower percentage of runoff in the south-west Slovakia where the CIE catchment is located. The period 1988-2007 was also indicated as an extraordinary warm by Faško et al. (2008). An increase in evapotranspiration as a result of increasing temperature in the last eighty years was also shown e.g. by Labudová et al. (2015). The magnitude of the upward trend in average annual air temperature is similar in the whole territory of Slovakia despite the very complex climatic conditions of the country.

Due to lower evaporation in winter, the winter precipitation is crucial for groundwater recharge. A decrease in winter precipitation totals can result in shrinking of groundwater resources that are not able to yield sufficient water supply in season with high evaporation i.e. in summer. All the rivers have natural regimes, therefore a consequence of intermittency is a very low abstraction of water for agriculture or water supply.

Therefore, we can conclude that the most important factors differentiating zero-flow characteristics are spatial lo- cation, groundwater storage properties and catchment elevation.

Regarding the timing of the onset, the mean dates $\bar{\Theta}_{1 s t}$ of the annual onset ranged between the 9th July (BUD) and the 23rd November (SLA). The dates of the onset are highly concentrated in most rivers, apart from the MYJ and SLA, because the mean resultant length $\bar{r}_{1 s t}$ is at least equal to 0.9 . This shows a very low dispersion of the dates. It is worth noting that $\bar{\Theta}_{1 s t}$ is similar within the second and the third group. The zero-flow events from the TUR and BOD rivers (second group) have a mean angular date of onset around 5th August while the CIE and CHL rivers (third group) have an onset date of 23rd July and 15th August, respectively. Very similar (identical) $\bar{r}_{1 s t}$ values feature in the second (third) group, too. Furthermore, the mean angular values and the mean resultant lengths of all events are similar within the second and the third group. The mean dates and the concentration of dates are more dispersed in the first group (MYJ, BUD, SLA rivers). The main cause behind this is the short sample length because the zero-flows occurred only twice in the MYJ and SLA rivers. Therefore, the angular characteristics are less helpful for these rivers.

The angular dates and the main characteristics of the onsets in the BUD river are depicted in Figure 4. The mean date $\bar{\Theta}_{1 s t}$ is around 9th July. The high concentration of dates is evident because the four dates are located near each other resulting in $\bar{r}_{1 s t}=0.9$.

A deeper insight into the dates of zero-flows in the CHL river allows recognition of most dates in August and September, respectively. This result 


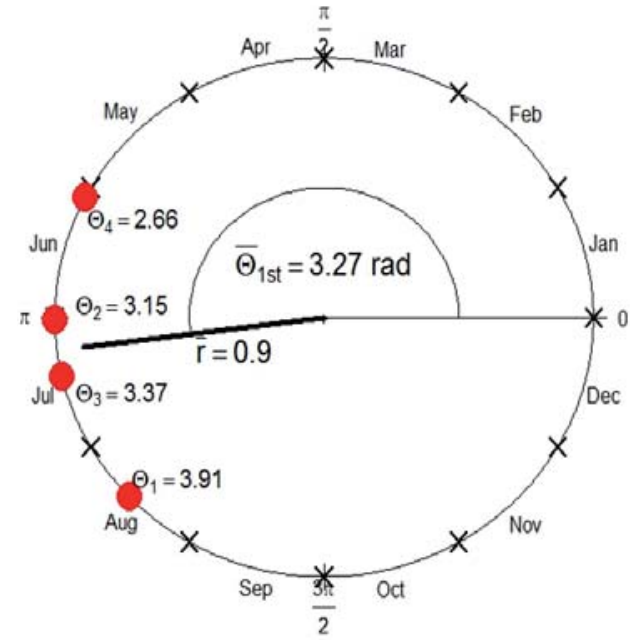

FIGURE 4. The angular dates of the first annual zero-flow days and the mean angular value of these dates in the BUD river. The length of the left arm of the angle is the mean resultant length

corresponds with those of Labudová et al. (2015) who identified August as the driest month in the East Slovakian Lowland using both the SPI and SPEI. In the CIE Danubian Lowland, the months with the lowest SPI are in winter season while the month with the highest evapotranspiration is August (Labudová et al. 2015) which explains the zero-flows in August, September and October in the CIE river. On the other hand, significant increasing weak trend in July precipitation total was detected by Zeleňáková et al. (2017) in the south-west part of Slovakia where the CIE catchment is located. However, this trend is often accompanied by prolonged drought episodes and very intense precipitation. The very intense precipitation is ineffective in water yield to ecosystem, especially after long drought, because infiltration is impeded by a very solid topsoil layer. After Labudová et al. (2015), the increase in monthly temperatures differs wherein January, June, July and August are the most considerable.

In light of this we can conclude that zero-flows are caused by enhanced evapotranspiration and prolonged periods without precipitation while the effects can be extended to several weeks.

\section{CONCLUSIONS}

Intermittent rives are rare in Slovakia. However, more zero-flow events were recorded after the year 1980 than before. The catchments of intermittent rivers differ by elevation and by location because the five southern rivers have higher frequency of intermittence than the two northern rivers. The zero-flow events had the largest intensity in two rivers from the Danubian Lowland and from the East Slovakian Lowland.

The possible causes behind the zero-flow events in various parts of Slovakia are the increasing temperature resulting in increasing evapotranspiration and decreasing air humidity. Another cause is the high variability in precipitation that results in prolonged drought periods.

Results of this study can be helpful in river management activities and can reduce the impact of river intermittence.

\section{Acknowledgement}

This study is a part of research done in a frame of the CA COST Action CA15113 Science and Management of Intermittent rivers and Ephemeral Streams (SMIRES). This work was also supported by the Slovak Research and Development Agency under Contract APVV-15-0497 and VEGA Grant 1/0710/15. 


\section{REFERENCES}

ACUNA V., DATRY T., MARSHALL J., BARCELO D., DAHM C.N., GINEBREDA A., McGREGOR G., SABATER S., TOCKNER K., PALMER M.A. 2014: Why Should We Care About Temporary Waterways? Science 343 (6175): 1080-1081 .

BANASIK K., HEJDUK L. 2012: Longterm changes in runoff from a small agricultural catchment. Soil \& Water Res. 7 (2): 64-72.

BANASIK K., HEJDUK L., HEJDUK A., KAZNOWSKA E., BANASIK J., BYCZKOWSKI A. 2013: Long-term variability of runoff from a small catchment in the region of the Kozienice Forest. Sylwan 157 (8): 578-586.

BARAN-GURGUL K., RACZYŃSKI K. 2016: Dynamika występowania niżówek w rzekach górskich i wyżynnych na przykładzie Wisłoki i Górnego Wieprza. Cz. 1. Sezonowość [Dynamics of low flows in mountain and upland rivers on example of Wisłoka and Upper Wieprz rivers. 1. Seasonality]. Woda - Środowisko - Obszary Wiejskie 16, 4 (56): 17-31.

BOND N.R., COTTINGHAM P. 2008: Ecology and hydrology of temporary streams: implications for sustainable water management. eWater Technical Report. eWater Cooperative Research Centre, Canberra. Retrieved from: http://ewatercrc. com.au/reports/Bond_Cottingham 2008 Temporary_Streams.p̄̄ff.

DATRY T., CORTI R., FOULQUIER A., Von SCHILLER D., TOCKNER T. 2016: One for all, all for one: a global river research network. EOS Am. Geophys. Un. 97 (15): 13-15.

DATRY T., LARNED S.T., TOCKNER K. 2014: Intermittent rivers: A Challenge for Freshwater Ecology. BioScience 64 (3): 229-235. DOI 10.1093/biosci/bit027

DINGMAN S.I. 2002: Physical Hydrology. Prentice Hall, Upper Saddle River NJ.

DÖLL P., SCHMIED H.M. 2012: How is the impact of climate change on river flow regimes related to the impact on mean annual runoff? A global-scale analysis. Environ. Res. Let. 7: 14-37.

FAŠKO P., LAPIN M., PECHO J. 2008: 20-year extraordinary climatic period in Slovakia. Slovak Meteorol. J. 11: 99-105.

FENDEKOVÁ M., POÓROVÁ J., SLIVOVÁ V. (Eds.) 2017: Hydrological drought in Slovakia and it prediction. Comenius University, Bratislava [in Sovak].

GAUSTER T. 2017: The R package smires (Science and Management of Intermittent rivers and Ephemeral Streams). Version 0.5 .

GUSTARD A., DEMUTH S. 2008: Manual on low-flow estimation and prediction. World Meteorological Organization, Geneva. Retrieved from: http://www.wmo.int/pages/ prog/hwrp/publications/low-flow_estimation_prediction/WMO\%201029\%20en. pdf.

JOKIEL P., STANISŁAWCZYK B. 2016: Zmiany i wieloletnia zmienność sezonowości przepływu wybranych rzek Polski. UJ Pr. Geogr. 144: 9-33. DOI 10. 4467/20833113PG.16.001.5126

LABUDOVÁ L., FAŠKO P., IVAŇIÁKOVÁ G. 2015: Changes in climate and changing climate regions in Slovakia. Morav. Geogr. Rep. 23: 71-82.

LABUDOVÁ L., LABUDA M., TAKÁČ J. 2017: Comparison of SPI and SPEI applicability for drought impact assessment on crop production in the Danubian Lowland and the East Slovakian Lowland. Theor. Appl. Climatol. 128: 491-506. DOI 10.1007/s00704-016-1870-2

LAPIN M., GERA M., HRVOL' J., MELO M., TOMLAIN J. 2009: Possible impacts of climate change on hydrologic cycle in Slovakia and results of observations in 1951-2007. Biologia 64 (3): 454-459.

LARNED S.T., DATRY T., ARSCOTT D.B., TOCKNER K. 2010: Emerging concepts in temporary- river ecology. Freshwater Biol. 5: 717-738.

LEIGH C., BOULTON A.J., COURTWRIGHT J.L., FRITZ K., MAY C.J., WALKNER R.H., DATRY T. 2016: Eco- 
logical research and management of intermittent rivers: an historical review and future directions. Freshwater Biol. 61 (8): 1181-1199.

LIVADA I., ASIMAKOPOULOS D.N. 2005: Individual seasonality index of rainfall regimes in Greece. Clim. Res. 28 (2): 155-161.

MARDIA K.V., JUPP P.E. 2000: Directional statistics. Wiley Series in Probability and Statistics. John Wiley \& Sons, Chichester.

MARKHAM C.G. 1970: Seasonality of precipitation in the United States. Ann. $\begin{array}{lll}\text { Am. Assoc. Geogr. } 60 & \text { (3): } 593-\end{array}$ -597. DOI 10.1111/j.1467-8306.1970. tb00743.x

MELO M., LAPIN M., DAMBORSKÁ I. 2007: Detection of climatic trends and variability at Hurbanovo. In: K. Střelcová, J. Škvarenina, M. Blaženec (Eds.). Bioclimatology and natural hazards. International Scientific Conference, 12-20.09.2007 Pol'ana nad Detvou.

MONIEWSKIP. 2016:Zmienność wydajności wybranych źródeł Polski i środkowej Europy w latach 2003-2014 [Discharge variability of selected springs of Poland and central Europe in the years 2003-2014]. Ann. UMCS Sect. B 71 (1): 29-44.

PECHO J., FAŠKO P., MIKULOVÁ K., LAPIN M., ŠŤASTNÝ P. 2009: Long-term changes of snow cover regime in connection with observed solid, liquid and mixed precipitation ratio trends in Slovakia. 9th Annual Meeting of the European Meteorological Society, 9th European Conference on Applied Meteorology (ECAM), 28.09-02.10.2009 Toulouse.

PETERSEN T., DEVINENI N., SANKARASUBRAMAANIAN A. 2012: Seasonality of monthly runoff over the continental United States: Causality and relations to mean annual and mean monthly distributions of moisture and energy. J. Hydrol. 468-469: 139-150.

PINIEWSKI M., MARCINKOWSKI P., KUNDZEWICZ Z.W. 2018: Trend detection in river flow indices in Poland.
Acta Geophys. DOI 10.1007/s11600018-0116-3.

R CORE TEAM 2017: R: A language and environment for statistical computing. R Foundation for Statistical Computing, Vienna, Austria.

STUBBINGTON R., CHADD R., CSABAI Z., MILIŠA M., MORAIS M., MUNNÉ A., PAŘIL P., PEŠIĆ V., TZIORTZIS I., VERDONSCHOT R.C.M., DATRY T. 2017: Biomonitoring of intermittent rivers and ephemeral streams in Europe: Current practice and priorities to enhance ecological status. Sci. Total Environ. 615: 1096-1113. DOI 10.1016/ j.scitotenv.2017.09.137

VOLOŠČUK I., UHLIAROVÁ E., SABO P., ŠKODOVÁ M., ŠVAJDA J. 2016: Succession dynamics of vegetation in the Slovak Karst Biosphere Reserve Landscape (Western Carpathians). Ekológia (Bratislava) 35 (1): 13-31.

WIĘZIK B. 2015: Hydrological data for designing of surface water intakes. Seminar of the Association of Polish Hydrologists - SHP, 18.15.2015 Warszawa. Retrieved from: http://www.shp.org.pl/wp-content/uploads/2015/10/seminarium_shp_ wiezik_2015 -.pdf.

ZELEŇÁK̄OVÁ M., VIDO J., PORTELA M.M., PURCZ P., BLIŠTAN P., HLAVATÁ H., HLUŠTIK P. 2017: Precipitation Trends over Slovakia in the Period 1981-2013. Water 9 (12): 922. DOI 10.3390/ w912092

Streszczenie: Charakterystyki przeptywu sporadycznie wysychajacych rzek w Stowacji. Rzeki sporadycznie wysychające są to takie, które mogą wysychać w okresie suszy. Mogą one być rzekami okresowymi, efemerycznymi, sezonowymi lub epizodycznymi. Analiza reżimu hydrologicznego tych rzek jest ważna z punktu widzenia oceny zasobów wodnych, gdyż zmiany charakterystyk przepływu takich rzek mogą wpływać na zmiany w zasilaniu zbiorników wodnych, takich jak jeziora, mokradła i torfowiska, a przez to oddziaływać na zlewnie sąsiednie i cały region. W ostatnim czasie odnotowano rosnącą liczbę rzek spora- 
dycznie wysychających, w tym efemerycznych (skrót $\mathrm{z}$ ang. IRES), oraz wydłużenie okresu, w którym przepływ w rzece jest zerowy. Zmiany te są skutkiem zmian klimatycznych oraz działań antropogenicznych. Przedmiotem badań były rzeki w Słowacji, które sporadycznie wysychaja. W badaniach zastosowano metody statystyczne. Obliczono charakterystyki okresu z zerowym przepływem, czasu trwania najdłuższego okresu z zerowym przepływem oraz pory jego występowania. W ocenie czasu występowania takiego przepływu wykorzystano statystyki kołowe. Dokonano analizy porównawczej między zlewniami. Wskazano zmienność opadu oraz wzrost temperatury jako możliwe czynniki powodujące wysychanie rzek w badanych zlewniach.
Stowa kluczowe: rzeki sporadycznie wysychające, IRES, zerowy przepływ, charakterystyki periodyczności, statystyki kołowe

$M S$ received 17.07.2018

MS accepted 13.08.2018
Authors' address:
Agnieszka Rutkowska
Katedra Zastosowań Matematyki
Uniwersytet Rolniczy w Krakowie
ul. Balicka 253C, 30-198 Kraków
Poland
e-mail: rmrutkow@cyf-kr.edu.pl 